\title{
Perencanaan Pemasaran Tahu Tuna pada Usaha Mikro Nabilla Makmur di Pacitan, Jawa Timur
}

\author{
NI LUH MADE RATNA HAPSARI PUTRI, DWI PUTRA DARMAWAN, \\ PUTU UDAYANI WIJAYANTI
}

\author{
Program Studi Agribisnis, Fakultas Pertanian, Universitas Udayana \\ Jalan PB Sudirman Denpasar 80232 \\ Email: Ratnachacha29@gmail.com \\ dwiputradarmawan@yahoo.com
}

\begin{abstract}
Marketing Plan of Tuna Tofu at Micro Enterprise Nabilla Makmur in Pacitan, Eats Java
\end{abstract}

This study aimed to know the marketing plan of tuna tofu micro business of Nabilla Makmur in 2017 as a new pioneered business unit and having a bright sales prospect.. The data analysis used Smart Business Plan 8.0 program consisting of marketing plan variables. The company did not implement the target in sales, but within one month the company was able to produce up to 1,500 packs per month. Based on the results of internal and external factors analysis by maximizing the strength and exploiting the existing opportunities and minimizing the weaknesses and threats from outside by improving the quality of tuna tofu products and services to consumers, looking for new potential supplier areas, promotion through internet and mass media and additional personnel as company sales, and cooperation with gift shop around Pacitan.The strategy adopted by the company was a marketing mix strategy which consists of product strategy using packaging system using vacuum plastic, pricing strategy based on competitor price, and cost of principle sale price in determining selling price of tuna tofu, company distribution strategy through local sales in Pacitan city and sales in out of Pacitan city covering some big cities in Indonesia, company promotion strategy with good company name and through social media.

Keywords: tuna tofu, marketing plan, marketing strategy

\section{Pendahuluan}

\subsection{Latar Belakang}

Mewujudkan Indonesia menjadi negara yang mandiri serta mampu mengikuti perkembangan era globalisasi Indonesia menghadapi banyak sekali tantangan serta peluang. Memerlukan peningkatan efisiensi ekonomi, produktivitas tenaga kerja, dan konstribusi yang signifikan dari sektor pembangunan untuk dapat mecapai tujuan tersebut (Santoso, 2008). Salah satu cara yang dapat dilakukan agar nilai tambah suatu komoditas pertanian meningkat adalah dengan mengaitkan pertanian dengan industri pengolahan. Jika pertanian hanya berhenti sebagai aktifitas budidaya (onfarm agribusiness), maka nilai tambah yang dihasilkan akan relatif sangat kecil. Nilai 
tambah pertanian akan meningkat jika melalui proses pengolahan lebih lanjut atau kegiatan sampai kepada sektor hilir (off-farm agribusiness) yang menghasilkan bermacam-macam produk olahan (Sorga, 2016). Hasil olahan yang berbahan baku kedelai menjadi makanan antara lain: tahu, tempe, susu kedelai, tauco, dan kecap (Adisarwanto (2005) dalam Sorga (2016)).

Hampir seluruh komoditas pertanian di Indonesia dapat diolah, salah satunya adalah kedelai. Hasil olahan yang berbahan baku kedelai menjadi makanan antara lain: tahu, tempe, susu kedelai, tauco, dan kecap. Tahu merupakan salah satu olahan pangan yang sangat digemari oleh masyarakat Indonesia. Tahu pertama kali muncul di Tiongkok sejak zaman Dinasti Han sekitar 2.200 tahun lalu. Penemunya adalah Liu An (Hanzi) yang merupakan seorang bangsawan, cucu dari Kaisar Han Gaozu, Liu Bang yang mendirikan Dinasti Han (Rahmawati, 2016). Jenis tahu pada awalnya hanya ada satu macam,yaitu tahu putih. Seiring dengan perkembangan kuliner, jenis dan rasa tahu banyak mengalami perkembangan. Salah satu bentuk olahannya adalah tahu tuna. Nabilla Makmur merupakan salah satu usaha mikro tahu tuna dari banyak usaha pengolahan tahu tuna yang ada di Pacitan. Nabilla Makmur masih terbilang perusahaan yang baru dibangun dibandingkan dengan perusahaan pesaing lainnya sehingga omset dari perusaahan ini masih dibilang rendah. Selain omset juga dari segi pemasaran masih terbilang terbatas.

\subsection{Rumusan Masalah}

Berdasarkan dari uraian latar belakang di atas maka dapat dirumuskan masalah yaitu bagaimana pemasaran pada Nabilla Makmur untuk tahun 2016 dan proyeksi untuk tahun 2017.

\subsection{Tujuan Penelitian}

Berdasarkan permasalahan yang telah dikemukakan di atas, maka penelitian ini bertujuan untuk mengetahui pemasaran yang dilakukan oleh usaha mikro Nabilla Makmur untuk tahun 2016 dan proyeksi tahun 2017, dengan menggunakan program Smart Business Plan 8.0.

\section{Metode Penelitian}

\subsection{Penentuan Waktu dan Lokasi Penelitian}

Penelitian ini dilakukan mulai bulan Juni sampai dengan Agustus 2016 di Nabilla Makmur yang berlokasi di RT 04 RW 04 Dusun Bengkal Desa Tanjung Sari, Kabupaten Pacitan, Provinsi Jawa Timur. Penentuan lokasi penelitian ini dilakukan dengan metode purposive sampling, yakitu suatu metode penentuan lokasi penelitian secara sengaja berdasarkan beberapa pertimbangan tertentu. Pertimbangan tersebut antara lain 1) Nabilla Makmur merupakan salah satu usaha mikro yang menjual olahan ikan tuna yaitu tahu tuna 2) Pemilik dan karyawan Nabilla Makmur sangat kooperatif dalam memberikan informasi yang dibutuhkan oleh mahasiswa dalam 
penelitian 3) Belum pernah dilaksanakan penelitian yang sama di perusahaan Nabilla Makmur.

\subsection{Informan Kunci, Jenis dan Sumber Data, dan Metode Pengumpulan Data}

Penelitian ini menggunakan informan kunci sebanyak dua orang untuk mendapatkan informasi dengan wawancara. Adapun yang digolongkan ke dalam informan kunci adalah pemilik Nabilla Makmur dan seorang karyawan bagian administrasi. Jenis data yang digunakan dalam penelitian ini adalah data kuantitaif dan data kualitatif. Data kuantitatif yaitu data yang berbentuk angka atau bilangan yang dapat diolah atau dianalisis menggunakan teknik perhitungan matematika atau statistika (Aedi, 2010). Data kualitatif adalah data berbentuk uraian terperinci, kutipan langsung, dan dokumentasi kasus (Moleong, 2005)

Sumber data yang digunakan dalam penelitian ini yaitu sumber data primer dan sumber data sekunder. Sumber data primer adalah data yang diperoleh langsung dari sumber pertama (perusahaan), yaitu berupa keterangan - keterangan langsung dari pihak manajemen perusahaan (Hasan, 2002). Sumber data sekunder adalah data yang diperoleh dari instansi yang berhubungan dengan penelitian ini dan juga dari buku buku laporan penelitian lainnya (Sugiyono, 2009). Metode pengumpulan data yang digunakan dalam penelitian ini yaitu meliputi observasi, wawancara, dan dokumentasi.

\subsection{Metode Analisis Data, Variabel dan Pengukuran Variabel, dan Batas Operasional}

Data yang bersifat kuantitatif dan kualitatif yang telah terkumpul kemudian dianalisis lebih lanjut secara deskriptif kualitatif. Analisis deskriptif kualitatif bertujuan untuk menggambarkan secara tepat keadaan dari obyek penelitian. Data dianalisis dengan menggunakan program Smart Business Plan 8.0 yaitu suatu program komputer pengolah data kuantitatif maupun data kualitatif untuk menyusun suatu perencanaan pemasaran atau perencanaan bisnis, dengan langkah-langkah yang telah tersedia dan siap digunakan untuk jangka waktu tertentu dengan batasan minimal satu tahun kedepan.

Variabel dan pengukuran varabel yang digunakan dalam penelitian ini adalah variabel perencanaan pemasaran yang terdapat dalam program Smart Business Plan 8.0, seperti variabel harga, jumlah produk, jenis produk, variabel internal (kekuatan dan kelemahan yang terdapat dalam perusahaan) maupun variabel eksternal (peluang dan ancaman yang mempengaruhi perusahaan).

Batasan operasional dalam penelitian ini antara lain perencanaan pemasaran, misi perusahaan, gambaran produk, kekuatan perusahaan, kelemahan perusahaan, ancaman perusahaan, strategi pemasaran secara umum, target, segmentasi pasar, dan contingency plans. 


\section{Hasil dan Pembahasan}

\subsection{Misi dan Sasaran Perusahaan}

Misi dari usaha mikro Nabilla Makmur adalah untuk memenuhi kebutuhan konsumen akan ikan terutama dalam produk olahan ikan tuna berupa tahu tuna. Dalam perbulannya Nabilla Makmur mampu berproduksi mencapai 1.500 bungkus produk tahu tuna. Setiap bungkus tahu tuna berisi 10 buah tahu tuna dengan berat masing - masing 400 gram per bungkus.

Tabel 1.

Volume Penjualan Tahu Tuna

\begin{tabular}{lcccc}
\hline \multirow{2}{*}{ Uraian } & \multicolumn{5}{c}{ Tahun } \\
\cline { 2 - 5 } & 2014 & 2015 & 2016 & 2017 \\
\hline Penjualan (bungkus)/400 gr & 10.734 & 14.330 & 15.471 & 18.677 \\
Pertumbuhan (\%) & - & 33,5 & 8,0 & 20,0 \\
\hline Sunnty
\end{tabular}

Sumber : Data Primer diolah 2016

Pada tahun 2015 volume penjualan meningkat sebesar 33,5 \% dari tahun 2014 atau meningkat sebesar 3.596 bungkus. Tahun 2016 volume meningkat menurun sebesar $8 \%$ dibandingkan tahun 2015 atau naik sebsesar 1.141 bungkus. Sesuai dengan penghitungan least square method pada tahun 2017 perusahaan diproyeksi mampu meningkatkan penjualan sebesar 18.677 bungkus atau meningkat sebesar 20 $\%$ dibandingkan dengan tahun sebelumnya. Perusahaan merasa optimis dengan proyeksi peningkatan penjualan sebesar 20\% karena pada tahun 2017 perusahaan berencana untuk menambah pasokan produk tahu tuna ke dalam toko oleh - oleh yang berada di kota Pacitan.

\subsection{Bisnis Perusahaan}

Nabilla Makmur merupakan sebuah perusahaan yang didirikan oleh Yoyok Dwi Kuncoro selaku pemilik perusahaan. Perusahaan ini bergerak dalam bidang pengolahan dan pemasaran ikan tuna berupa produk tahu tuna. Perusahaan ini didirikan pada tahun 2012 dan mulai beroperasi pada tahun 2013. Tahu tuna merupakan olahan yang berbahan dasar tahu dan ikan tuna. Produk ini berkembang untuk memenuhi permintaan konsumen akan tahu dan ikan khusunya ikan tuna. Produk ini termasuk dalam kategori frozen food atau makanan beku. Pemasaran tahu tuna pada Nabilla Makmur dilakukan dengan tiga cara yaitu melalui telepon menawarkan ke konsumen lokal, pembeli datang langsung ke lokasi untuk membeli barang, serta pembeli mengorder barang, dan meminta untuk mengantarkannya.

\subsection{Analisis Pasar}

Pasar Nabilla Makmur masih dalam tahap pasar lokal. Pasar lokal tersebut merupakan konsumen dari kota Pacitan sendiri mau pun konsumen dari kota - kota besar lain di Indonesia seperti Solo, Bogor, Jakarta, Yogyakarta, dan Surabaya. Perusahaan harus mampu untuk mengetahui keinginan atau kebutuhan konsumen 
untuk dapat memenuhi mutu dan kualitas produk yang unggul. kebutuhan konsumen antara lain kebutuhan akan protein nabati dan hewani, kebutuhan akan kandungan lemak omega-3, dan kebutuhan akan makanan bernilai gizi tinggi. Pesaing perusahaan adalah usaha mikro Eza Mandiri. Perusahaan ini memiliki persamaan dalam hal produk yang dipasarkan, sistem pengemasan, pemasaran produk, dan harga jual.

\subsection{Faktor Internal dan Eksternal Perusahaan}

Faktor lingkungan dapat dibagi menjadi dua yaitu faktor lingkungan internal dan faktor lingkungan eksternal (Swasta dan Irawan, 2005).

1. Faktor Internal

Faktor internal perusahaan Nabilla Makmur meliputi promosi, lokasi, pasar, volume penjualan, keragaman produk, sumberdaya manusia, serta hari dan jam kerja.

2. Faktor Eksternal

Faktor eksternal perusahaan Nabilla Makmur meliputi Inflasi, kenaikan tariff $\mathrm{BBM}$, listrik dan telefon, kemajuan teknologi informasi dan komunikasi, persaingan antara perusahaan tahu tuna, pertumbuhan penduduk, daya tawar konsumen, daya tawar pemasok,

\section{Analisis SWOT}

Menurut Rangkuti (2001), analisis SWOT adalah identifikasi berbagai faktor secara sistematis untuk merumuskan strategi perusahaan. Berdasarkan analisis faktor internal dan eksternal perusahaan, maka dapat diidentifikasikan kekuatan, kelemahan, peluang, dan ancaman usaha mikro Nabilla Makmur.

1) Kekuatan : Sistem vacuum packing tahu tuna yang bagus, nama baik perusahaan, karyawan berpengalaman, hari dan jam kerja yang efektif, lokasi perusahaan strategis

2) Kelemahan : pasar yang relatif kecil, produk yang hanya mampu bertahan selama 24 jam dalam suhu ruang, promosi yang lemah, modal untuk mengembangkan usaha yang rendah.

3) Peluang : kemajuan teknologi informasi dan komunikasi, perdagangan bebas, banyaknya jumlah tenaga kerja di pasar tenaga kerja, pertumbuhan penduduk dunia yang tinggi, pertumbuhan pasar yang baik

4) Ancaman : inflasi yang dapat memicu kenaikan upah dan gaji, kenaikan tarif BBM, listrik, dan telepon, kemungkinan pindahnya tenaga kerja ke perusahaan lain, munculnya perusahaan pesaing baru.

Sesuai dengan analisis SWOT didapatkan hasil sebagai berikut: 1) Berusaha meningkatkan pangsa pasar tahu tuna, 2) Berusaha mencari atau menambah jaringan distribusi baru, 3) Berusaha meningkatkan penjualan dengan meningkatkan kualitas produk yang ada sekarang, 4) Mencoba untuk melakukan diversifikasi usaha dengan memanfaatkan fasilitas yang ada, dan 5) Meningkatkan kualitas dan kesejahteraan karyawan. 


\subsection{Tujuan Perusahaan}

Nabilla Makmur mempunyai tujuan untuk terus meningkatkan nilai penjualan agar usaha semakin terus berkembang.

Tabel 2.

Perkembangan Kinerja Keuangan Nabilla Makmur

\begin{tabular}{lrrr}
\hline \multicolumn{1}{c}{ Uraian } & \multicolumn{1}{c}{2014} & \multicolumn{1}{c}{2015} & \multicolumn{1}{c}{2016} \\
\hline Penjualan (Rp) & 85.872 .000 & 114.640 .000 & 116.032 .500 \\
Volume penjualan (bungkus) & 10.734 & 14.330 & 15.471 \\
Biaya variable (Rp) & 51.403 .050 & 60.518 .500 & 54.122 .500 \\
Biaya tetap (Rp) & 7.896 .656 & 12.426 .656 & 14.614 .656 \\
Laba (Rp) & 26.572 .294 & 41.694 .844 & 47.295 .344 \\
\hline
\end{tabular}

Sumber : Data Primer diolah 2016

Dari data kinerja keuangan di atas dapat dilihat penjualan pada tahun 2014 sebesar Rp 85.872.000 dan mengalami peningkatan sebesar Rp 114.640.000 pada tahun 2015. Begitu pula dengan laba pada tahun 2014 sebesar Rp 26.572.294, dimana mengalami peningkatan sebesar Rp 41.694.844 pada tahun 2015. Peningkatan penjualan dan laba pada tahun 2015 disebabkan karena pada tahun tersebut konsumen sudah mulai mengenal produk tahu tuna Nabilla Makmur yang berimbas pada meningkatnya jumlah permintaan tahu tuna. Pada tahun 2016 perusahaan mengalami peningkatan penjualan sebesar $\mathrm{Rp} 116.032 .500$ dan peningkatan laba sebesar Rp 47.295.344 dibandingkan pada tahun 2015 . Peningkatan penjualan dan laba pada perusahaan berkaitan erat dengan semakin meluasnya pemasaran dan peningkatan permintaaan konsumen terhadap produk tahu tuna.

\subsection{Strategi Pemasaran Umum}

Strategi pemasaran umum meliputi target pasar dan posisi produk. Target pasar dari Nabilla Makmur adalah pasar lokal. Pasar lokal dalam hal ini meliputi masyarakat sekitar perusahaan dan juga masyarakat di luar kota. Pada tahun 2017 target pasar perusahaan masih menyasar pada toko oleh - oleh di kota Pacitan dan kota - kota besar seperti Solo, Bogor, Jakarta, Surabaya dan Yogyakarta. Posisi produk, tahu tuna merupakan makanan yang berbahan baku utama ikan tuna dan tahu. Bisnis ini memiliki prospek yang cerah sehingga banyak dari masyarakat yang kemudian mulai merintis usaha tahu tuna. 


\subsection{Strategi Bauran Pemasaran}

Menurut William M. Pride dalam Winardi (1989) ada empat model bauran pemsaran yaitu produk, harga, distribusi, dan promosi.

\section{1) Strategi Produk}

Perusahaan memasarkan produk kepada konsumen lokal baik konsumen yang berada pada sekitaran perusahan mau pun konsumen yang berada di luar kota. Konsumen yang disasar oleh perusahaan adalah konsumen di kota - kota besar seperti Solo, Jakarta, Surabaya, dan Jogja. Nabilla Makmur mempunyai keunggulan dari segi produk yaitu nama baik, kualitas produk yang bisa dikonsumsi disegala usia, dan pelayanan yang ramah.

\section{2) Strategi Harga}

Perusahaan menerapkan harga jual tahu tuna dengan berpatokan pada harga jual perusahaan pesaing, harga jual ditentukan dengan harga pokok penjualan. Nabilla Makmur menerapkan beberapa cara promosi antara lain melalui media social seperti facebook, instagram, web, dan media sosial lainnya. Promosi produk selain melalui media sosial perusahaan juga menawarkan langsung dari mulut ke mulut.

3) Strategi Distribusi

Perusahaan melakukan pemasaran lokal dengan cara penjualan langsung yaitu pembeli langsung datang ke perusahaan untuk membeli tahu tuna. Penjualan tidak langsung yaitu pembeli menghubungi perusahaan menggunakan telepon dan kemudian perusahaan akan mengirim tahu tuna kepada konsumen dengan menggunakan jasa pengiriman

\section{4) Strategi Promosi}

Nabilla Makmur menerapkan beberapa cara promosi antara lain melalui media sosial seperti facebook, instagram, web, dan media sosial lainnya. Promosi produk selain melalui media sosial perusahaan juga menawarkan langsung dari mulut ke mulut.

\subsection{Contingency Plans}

Contingency plans merupakan perencanaan perusahaan yang akan dijalankan apabila terjadi penurunan terhadap permintaan tahu tuna agar perusahaan dapat terus berproduksi. Nabilla Makmur selain memproduksi tahu tuna juga mempunyai rencana untuk memproduksi olahan ikan tuna yang lain seperti rolade ikan tuna, otak - otak tuna, lumpia tuna, dan siomay tuna. Harga dari produk olahan ikan tuna berkisar antara Rp 6.500 sampai dengan $\mathrm{Rp} 7.500$ pada tahun 2017.

Sesuai dengan penghitungan proyeksi dengan menggunakan least square methode perusahaan pada tahun 2017 yang memproyeksi pencapaian peningkatan volume penjualan sebesar $20 \%$ maka perusahaan berencana untuk memasukkan produk tahu tuna ke dalam toko oleh - oleh khas Pacitan dan terus berinovasi dalam hal peralatan untuk menunjang produksi tahu tuna. Inovasi dalam peralatan yang dimaksud adalah inovasi peralatan filling atau pengisi yang bertujuan untuk perusahaan agar mampu memproduksi produk tahu tuna lebih banyak dengan waktu 
yang lebih singkat. Perusahaan selain melakukan inovasi peralatan filling, juga terus berinovasi pada resep tahu tuna. Inovasi resep bertujuan agar tahu tuna yang dihasilkan oleh Nabilla Makmur mempunyai cita rasa yang enak dan berbeda dengan perusahaan pesaing lain.

\section{Kesimpulan dan Saran}

\subsection{Kesimpulan}

Dari hasil pembahasan yang telah dilakukan dapat disimpulkan bahwa:

1. Strategi bauran pemasaran perusahaan, strategi produk perusahaan menggunakan sistem pengemasan dengan plastik vakum dan pengepakannya menggunakan box, strategi harga berpatokan pada harga beli dan harga pesaing dalam penentuan harga jual tahu tuna, strategi distribusi perusahaan melalui penjualan lokal, strategi promosi perusahaan menggunakan media sosial dan mengandalkan nama baik perusahaan serta kenalan atau kolega yang menghubungkan perusahaan dengan calon pembeli baru.

2. Sesuai dengan least square methode proyeksi penjualan tahun 2017 untuk usaha mikro Nabilla Makmur adalah sebesar 18.677 bungkus atau meningkat sebanyak 20\% dibanding tahun 2016. Perusahaan optimis dengan proyeksi tersebut karena perusahaan berencana untuk menambah pasokan produk tahu tuna kedalam toko oleh - oleh di seluruh kota Pacitan.

\subsection{Saran}

Berdasarkan hasil analisis terhadap perencanaan pemasaran tahu tuna Nabilla Makmur dapat dikemukakan saran yang dapat dijadikan pertimbangan dalam menyusun dan menjalankan perusahaan pada masa yang akan datang sebagai berikut:

1. Perlu adanya kerjasama dengan pemasok ikan tuna untuk menjaga kelangsungan ketersediaan bahan baku ikan tuna yang berkulitas.

2. Menambah jalur distribusi dengan cara mempererat hubungan dengan distributor yang sudah ada dan membuka jalur distribusi baru.

\section{Ucapan Terimakasih}

Penelitian ini tidak mungkin terlaksana tanpa adanya bantuan dari berbagai pihak, maka dari itu pada kesempatan ini penulis menyampaikan rasa terimakasih kepada pemilik usaha mikro Nabilla Makmur yaitu Yoyok Dwi Kuncoro serta semua pihak yang membantu kelancaran penelitian ini hingga termuat di jurnal.

\section{Daftar Pustaka}

Aedi, Nur. 2010. Bahan Belajar Mandiri Metode Penelitian Pendidikan :Pengolahan dan Analisis Data Hasil Penelitian. Diunduh pada http://file.upi.edu. Diakses tanggal 4 Oktober 2016.

Hasan, M. Iqbal. 2002. Pokok - Pokok Metode Penelitian dan Aplikasinya. Bogor. Ghalia Indonesia. 
Moleong, Lexy J. 2005. Metode Penelitian Kualitatif. Bandung. PT. Remaja Rosdakarya

Rahmawati, Fitri. 2016. Materi Kegiatan: Teknologi Proses Pengolahan Tahu dan Pemanfaatan Limbahnya. Diunduh pada http://staff.uny.ac.id.pdf. Diakses pada tanggal 20 April 2016.

Rangkuti, F. 2001. Teknik Membuat Rencana Pemasaran. Cetakan kedua. Jakarta. PT. Gramedia Pustaka Utama.

Santoso, Taufan Sukmo. 2008. Analisis Finansial Usaha Kerupuk (Studi Kasus : Kerupuk Suka Asih (SKS) di Pondok Labu, Jakarta Selatan). Diunduh pada http://repository.uinjkt.ac.id0SUKMO\%20SANTOSO-FST.pdf. Diakses pada tanggal 05 Maret 2016.

Sorga, Sitri. 2016. Analisis Komparasi Nilai Tambah Dalam Berbagai Produk Olahan Kedelai Pada UD Di Kota Medan. Diunduh pada http://repository.usu.ac. Diakses tanggal 29 April 2016.

Sugiyono. 2009. Metode Penelitian Kuantitatif Kualitatif dan R\&D. Bandung. Alfabeta

Swastha, Basu dan Irawan. 2005. Manajemen Pemasaran Modern. Yogyakarta. Liberty.

Winardi. 1989. Aspek - Aspek Bauran Pemasaran. Bandung. Mandar Maju. 